\title{
Super-Eruptions and the Search for Extraterrestrial Intelligence (SETI)
}

\author{
Michael R. Rampino \\ Earth \& Environmental Science Program, New York University, 100 \\ Washington Square East, New York, NY 10003, USA and \\ NASA, Goddard Institute for Space Studies, 2880 Broadway, New York, \\ $N Y 10025$, USA
}

\begin{abstract}
Volcanic super-eruptions that produce $>1000 \mathrm{~km}^{3}$ of ejected material and $\geq 1000 \mathrm{Mt}\left(10^{15} \mathrm{~g}\right)$ of stratospheric aerosols and sub-micron dust may be capable of creating global climatic disturbances sufficient to cause a severe setback or crash of modern civilization. Eruptions of similar magnitude are estimated to occur on average about every 50000 to 100000 years, which may be considerably more frequent than impacts by asteroids and comets that could cause similar climatic disasters. Prediction, prevention, and mitigation of global volcanic climatic disasters are potentially more difficult than planetary protection from large impactors, so that volcanism might provide an ultimate limit on the longevity of technological civilizations. If the lifetime of technological civilizations were limited to less than 50000 years by volcanism, then the number of communicative civilizations in the Galaxy might be less than 1 per 10 million stars. Thus, super-eruptions on geologically active, habitable planets may strongly affect the prospects in radio telescopic SETI.
\end{abstract}

\section{Introduction}

The chances for communicative intelligence in the Galaxy is commonly represented by a combination of the relevant factors called the Drake Equation, which can be written:

$$
N=R * f_{p} n_{e} f_{l} f_{i} f_{c} L
$$

where $N$ is the number of intelligent communicative civilizations in the Galaxy; $R *$ is the rate of star formation averaged over the lifetime of the Galaxy; $f_{p}$ is the fraction of stars with planetary systems; $n_{e}$ is the mean number of planets within such systems that are suitable for life; $f_{l}$ is the fraction of such planets on which life actually occurs; $f_{i}$ is the fraction of planets on which intelligence of arises; $f_{c}$ is the fraction of planets on which intelligent life develops a communicative phase; and $L$ is the mean lifetime of such technological civilizations (Sagan 1973). At present, the only well-known number in the Drake Equation is $R *$, which is commonly taken as $10 \mathrm{yr}^{-1}$. Estimates for $\mathrm{N}$ have been grouped as pessimistic or optimistic, and published values of $\mathrm{N}$ vary from $\sim 0$ to $10^{8}$ (e.g., Sagan 1973).

The factors $f_{c}$ and $L$ may be limited in part by the occurrence of asteroid and comet impacts that could be catastrophic to technological civilizations (Sagan \& Ostro 1994; Chyba 1997). Present civilization, dependent largely on annual crop yields, is vulnerable to an impact winter that would result from dust 
lofted into the stratosphere by large impacts. Several authors have estimated the threshold impact size for global catastrophic climatic cooling and ozone layer destruction as a 1-2 km diameter asteroid (Chapman \& Morrison 1994; Toon et al. 1997; Chapman 2002). Such an impact would produce a crater $\sim 20-40 \mathrm{~km}$ in diameter, release about $10^{5}$ to $10^{6} \mathrm{Mt}$ (TNT equivalent) of energy, and is calculated to generate a global cloud consisting of $\sim 1000 \mathrm{Mt}$ of sub-micron dust (Toon et al. 1997). Chapman \& Morrison (1994) estimate that an impact of this size would kill $>1.5$ billion people through direct and non-direct effects.

Pope (2002), however, recently calculated that the amount of sub-micron dust produced by impacts has been greatly overestimated. Based on evidence at the Cretaceous-Tertiary boundary, Pope suggests that even the $10-\mathrm{km}$ diameter asteroid or comet that hit the earth 65 million years ago forming the Chicxulub impact structure produced less than $100 \mathrm{Mt}\left(10^{14} \mathrm{~g}\right)$ of sub-micron dust. His results suggest that the minimum size impactor able to create global climatic catastrophe (primarily from soot from global wildfires and sulfate aerosols from sulfur contained in the impactor) is a $3-\mathrm{km}$ diameter asteroid.

Impacts of these magnitudes are expected to occur on average about every million years for a $1 \mathrm{~km}$ diameter asteroid to once every 10 million years for a $3 \mathrm{~km}$ asteroid (Chapman \& Morrison 1994). Thus, civilization must develop science and technology sufficient to detect and deflect such threatening asteroids and comets on a time scale shorter than the typical times between catastrophic impacts. This factor would apparently select against civilizations that are longlived but non-technological (e.g. dolphin poets) (Sagan \& Ostro 1994).

\section{Volcanic Eruptions and Climate}

Volcanic eruptions occur on geologically active earthlike planets. On the Earth, explosive volcanism is generally concentrated at subduction zones and continental rift environments (Simkin \& Siebert 1994). Dust and sulfuric acid aerosols generated by explosive eruptions and by some large effusive lava-flow eruptions, and distributed in the upper atmosphere, can act to cool the planet (Rampino et al. 1988; Robock 2000). Historic eruptions have been associated with significant global and regional climatic cooling and related disturbances of agriculture, transportation and public health (Rampino et al. 1988; Stothers 1984, 1999, 2000).

The scale of explosive magnitude, the Volcanic Explosivity Index (or VEI) (Newhall \& Self 1982) is based on the volume of the erupted products (and initially the height of the volcanic eruption column). VEI's range from VEI $=0$ for strictly non-explosive eruptions to VEI $=8$ for explosive eruptions producing $\sim 10^{12} \mathrm{~m}^{3}$ bulk volume of ash and pumice. Eruptions also differ in the amounts of sulfur-rich gases released to form stratospheric aerosols, and thus the sulfur content of the magma and the efficiency of degassing are also important factors in atmospheric impact (Rampino \& Self 1984).

Historic explosive eruptions have ranged from VEI 0 to 7 and stratospheric aerosols produced by eruptions of VEI 3 to 7 (representing erupted volumes of ejecta from $<1 \mathrm{~km}^{3}$ to a few tens of $\mathrm{km}^{3}$, and stratospheric clouds ranging from $\sim 10$ to 100 megatons of aerosols and dust) have been capable of cooling the Earth's global climate by a few tenths of $a^{\circ} \mathrm{C}$ (Rampino \& Self 1984; Robock 2000).

The largest known eruption of the last millennium, the 1815 eruption of Tambora volcano in Indonesia (VEI $=7$ ), produced $\sim 100$ megatons of stratospheric aerosols and dust, and is associated with a peak northern hemisphere 
cooling of $\sim 1^{\circ} \mathrm{C}$ (Stothers 1983). The Tambora eruption was followed by unusually cold conditions in 1816, which became known as the "year without a summer" in Europe and eastern North America, and seems to have precipitated the last great subsistence crisis in western Europe (Stothers 1983; Harington 1992). An even denser aerosol cloud is reported in AD 536, although the source volcano remains unknown (Stothers 1984; Baillie 1993), and an eruption in AD 1258 may have produced a global aerosol cloud in excess of that of Tambora (Stothers 2000).

\section{Super-eruptions}

Historic eruptions were quite small, however, compared to some volcanic events in the geologic record of the last million years that may truly be called "supereruptions". The largest recorded explosive eruptions (VEI $=8$ and $\geq 1000 \mathrm{~km}^{3}$ of bulk deposits) are large caldera-forming eruptions that produce large-volume pyroclastic flow deposits (ignimbrites) and widespread ashfall. The greatest explosive eruption in the last few hundred thousand years was the Toba (Sumatra) event of $\sim 74000$ years ago (Rose and Chesner 1990; Rampino \& Self 1992, 1993), which erupted at least $2800 \mathrm{~km}^{3}$ of magma (as ignimbrite, pumice fall, and ash), and is estimated to have produced from 1000 to $10000 \mathrm{Mt}$ of stratospheric dust and sulfuric acid aerosols. Extrapolation of the data of Pyle et al. (1996) to VEI 8 eruptions gives about $1000 \mathrm{Mt}$ of $\mathrm{SO}_{2}$ release. The aerosols persisted for up to 6 years in the upper atmosphere (Zielinski et al. 1996).

Based on scaling up from smaller eruptions and simple models, stratospheric aerosol loading of $\sim 1000 \mathrm{Mt}$ is predicted to have caused a "volcanic winter", with regional cooling up to $15^{\circ} \mathrm{C}$ and a global cooling of 3 to $5^{\circ} \mathrm{C}$ for several years (Rampino \& Self 1992, 1993). Such a drastic cooling is estimated to have disastrous effects on tropical and temperate vegetation and ecosystems (Rampino \& Ambrose 2000). All above-ground tropical vegetation would have been killed by sudden hard freezes, and $50 \%$ die off of temperate forests is predicted for freezes during the growing season. Recent GCM modeling suggests an even more drastic cooling of $10^{\circ} \mathrm{C}$ for the globe and up to $20^{\circ} \mathrm{C}$ for large regions of the Earth for a Toba-sized eruption (Jones \& Stott 2002). By contrast, Oppenheimer (2002) suggests that the effects of the Toba eruption may be overestimated, and proposes that the post-Toba cooling may have been as little as $1^{\circ} \mathrm{C}$.

Evidence from human genetic studies have been interpreted as indicating a severe human population bottleneck, with reductions to a total population as small as a few thousand, at a time just prior to $\sim 60000$ years ago (Harpending et al. 1993; Ambrose 1998). This is roughly the same interval as the great Toba eruption, and a cause and effect relationship with Toba has been proposed (Ambrose 1998), and is supported by the predicted severe ecological effects of the eruption (Rampino \& Ambrose 2000; Rampino 2002). This event would have represented a near-extinction for humans, and suggests that the drastic effects of large volcanic eruptions on pre-civilized human societies may be capable of preventing the evolution of technological civilizations.

Decker (1990) proposed that if all magnitude 8 eruptions in the recent past left calderas that have been recognized, then the frequency of VEI 8 eruptions would be $\sim 2 \times 10^{-5}$ eruptions per year, or one VEI 8 eruption about every 50000 years. As the last super-eruption of $>1000 \mathrm{~km}^{3}$ was the Toba event of $\sim 74000$ yrs ago, the average time between super-eruptions may be closer to $100000 \mathrm{yrs}$. 


\section{Can Super-Eruptions be Predicted or Mitigated?}

Volcanic eruptions are difficult to predict. Prediction strategies have included: 1) recognition of patterns of eruptions at specific volcanoes (e.g., Scandone et al. 1993); 2) precursor activity of various kinds (e.g., Chouet 1996, Self \& Mouginnis-Mark 1995; Nazzaro 1998); 3) regional and global distribution of eruptions in space and time (Carr 1977); and 4) theoretical predictions based on behavior of materials (Voight 1988, Voight \& Cornelius 1991). Thus far, however, no method has proven successful in consistently predicting the timing, and perhaps more importantly, the magnitude of the resulting eruption or its magmatic sulfur content and release characteristics.

It is difficult to see how super-eruptions could be predicted, and even if they could be accurately forecast, and local precautions and evacuations could take place, the regional and global effects of the ash fallout and aerosol clouds on climate, agriculture, health and other aspects of modern civilization could not be easily prevented or mitigated significantly. The major effect on civilization would be through collapse of agriculture as a result of the loss of one or more growing seasons (Toon et al. 1997). This would be followed by famine, the spread of infectious diseases, breakdown of infrastructure, financial collapse, social and political unrest, and conflict.

Volcanic winter predictions range from global cooling of 3 to $5^{\circ} \mathrm{C}$ for several years and regional cooling up to $15^{\circ} \mathrm{C}$ (Rampino \& Self 1992; Rampino \& Ambrose 2000) to more severe $10^{\circ} \mathrm{C}$ decreases in global temperature and greater than $20^{\circ} \mathrm{C}$ regional cooling based on recent Global Climate Modeling (Jones \& Stott 2002). These conditions would devastate the major food-growing areas of the world. In the American Midwest and the Ukraine crops can be severely injured by a 3 to $4^{\circ} \mathrm{C}$ temperature decrease during the growing season (Harwell \& Hutchinson 1985). In Canada, a 2 to $3^{\circ} \mathrm{C}$ average local temperature drop would destroy wheat production, and 3 to $4{ }^{\circ} \mathrm{C}$ would halt all Canadian grain production. At lower latitudes, the Asian rice crop could be destroyed by a single night of below-freezing temperatures during the growing season. Severe climate would also interfere with global transportation of foodstuffs and other goods. Super-eruptions might lead to longer term climatic change through positive feedback effects on climate such as cooling the surface oceans, formation of sea-ice, or increased land ice (Rampino \& Self 1992, 1993), prolonging recovery from the "volcanic winter".

The location of a super-eruption can also be an important factor in its regional effects. Eruptions from the Yellowstone Caldera over the last $2 \mathrm{Myr}$ include the $2500 \mathrm{~km}^{3}$ Huckleberry Ridge Tuff (2 Myr), the $280 \mathrm{~km}^{3}$ Mesa Falls Tuff $(1.3 \mathrm{Myr})$ and the $1000 \mathrm{~km}^{3}$ Lava Creek Tuff $(0.6 \mathrm{Myr})$. Each of these produced thick ash deposits over the western and central U.S. (compacted ash thicknesses of $0.2 \mathrm{~m}$ occur $\sim 1500 \mathrm{~km}$ from the source; Wood \& Kienle 1990). In addition to the global climatic consequences of these Yellowstone super-eruptions, they would have devastated the major grain-producing areas in the breadbasket of North America, preventing agricultural recovery for years.

At present, a global stockpile equivalent to a 2-month global supply of grain exists (Smith, 2000), which is about $15 \%$ of annual consumption. Schneider \& Londer (1984) suggested that a minimum world level of accessible grain stocks near $15 \%$ of global utilization should be maintained as a hedge against year- 
to-year production fluctuations due to climatic and socio-economic disruptions. For a super-eruption climate catastrophe, however, several years of growing season might be curtailed (Zielinski et al. 1996; Rampino \& Ambrose 2000), and hence a much larger stockpile of grain and other foodstuffs would have to be maintained, along with effective strategies for rapid global distribution during the crisis interval. Burrows \& Shapiro (1999) propose that development of an interplanetary repository for important aspects of terrestrial civilization. This would mean the transfer of human civilization, along with all technological and cultural information, to other places in the Solar System for safekeeping. The repository would be a means of providing a backup system for the planet, fostering recovery of terrestrial civilization in the wake of global disasters.

\section{Conclusions}

Many recent studies have investigated the possibilities of deflection or destruction of $\geq 1-\mathrm{km}$ diameter asteroids and comets (e.g., Gehrels 1994; Remo 1997) that could cause "impact winter" conditions and threaten civilization (Chyba 1997), and such planetary protection technology has been deemed a prerequisite for long-term survival of communicative planetary civilizations.

Estimates of the frequency of volcanic super-eruptions that could cause similar "volcanic winter" conditions suggest that they should occur about once every 50000 to 100000 years (Rampino 2002). This is a factor of 10 times more frequent than impact winter-causing asteroid or comet collisions that are estimated to occur about once every few hundred thousand years (Chapman 2002). If Pope (2002) is correct, and a minimum of a $3 \mathrm{~km}$ diameter asteroid (every few million years) is required to threaten civilization, then super-eruptions could be much more frequent than civilization-busting impacts. Furthermore, there might be little even a highly technological civilization could do to prevent (or even predict) a volcanic climatic catastrophe.

If, for example, the Drake Equation reduces to $N \sim 10^{-1} L$, as has been suggested (Sagan 1973), and if we take the estimate of a super-eruption every 50000 years, then $N$ could be $5 \times 10^{3}$ in the volcanism-limited case. This would mean that $<1$ star in 10 million in our Galaxy of several hundred billion stars might have planets with communicative intelligence, and such civilizations could be separated by $>1000$ light years. Thus, super-eruptions on geologically active habitable planets may strongly affect the prospects in searches for ETI.

\section{References}

Ambrose, S. H. 1998, J. Human Evolution, 34, 623

Baillie, M. G. L. 1993, The Holocene, 4, 212

Burrows, W. E., \& Shapiro, R. 1999, Ad Astra Sept/Oct, 18

Carr, M. J. 1977, Science, 197, 655

Chapman, C. R. 2002, Geol. Soc. Am. Spec. Pap., 356, 7

Chapman, C. R., \& Morrison, D. 1994, Nature, 367, 33

Chouet, B. A. 1996, Nature, 380, 316

Chyba, C. F. 1997, in Astro and Bioch Origins and the Search for Life in the Universe, ed. C.B. Cosmovici, et al. (Bologna: Editrice Compositori) 57

Decker, R. W. 1990, in Thera and the Aegean World III, 2, ed. D. A. Hardy, et al., (London: The Thera Foundation), 444 
Gehrels, T., ed. 1994, Hazards Due to Comets \& Asteroids, (Tucson: Univ of Arizona Press)

Harington, C. R., ed. 1992, in The Year Without a Summer? World Climate in 1816, (Ottawa: Canadian Museum of Nature)

Harpending, H. C. et al. 1993, Current Anthropol., 34, 483

Harwell, M. A., \& Hutchinson, T. C. ed. Environmental Consequences of Nuclear War, (New York: Wiley)

Jones, G. S., \& Stott, P. A. 2002, in AGU Chapman Conf. Proc., Volcanism and the Earth's Atmosphere, (Washington: Amer. Geophys. Union), 45

Nazzaro, A. 1998, Annali di Geofisica, 41, 555

Newhall, C. A., \& Self, S. 1982, J. Geophys. Res., 87, 1231

Oppenheimer, C. 2002, Quat. Sci. Rev., 21, 1593

Pope, K. 2002, Geology, 30, 99

Pyle, D. M., Beattie, \& Bluth, G. J. S. 1996, Bull. Volcanol., 57, 663

Rampino, M. R. 2002, Icarus, 156, 562.

Rampino, M. R., \& Ambrose, S. 2000, Geol. Soc. Am. Spec. Pap., 345, 71

Rampino, M. R., \& Self, S. 1984, Nature, 310, 677

Rampino, M. R., \& Self, S. 1992, Nature, 359, 50

Rampino, M. R., \& Self, S. 1993, Quat. Res., 40, 269

Rampino, M. R., Stothers, R. B., \& Self, S. 1988, Ann Rev Earth Planet Sci, 16, 73

Remo, J. L., ed. 1997, in Near Earth Objects, (NY: Acad Sci Ann), 822

Robock, A. 2000, Rev. Geophys., 38, 191

Rose, W. I., \& Chesner, C. A. 1990, Global and Planet Change, 89, 269

Sagan, C. ed. 1973, Communication with ETI, (Cambridge: MIT Press)

Sagan, C., \& Ostro, S. 1994, Issues Science \& Technol, 10, 67

Scandone R. G., Arganese, G., \& Galdi, F. 1993, J. Volc. Geoth. Res., 58, 263

Schneider, S., \& Londer, R. 1984, The Coevolution of Climate \& Life, (SF: SC)

Self, S., \& Mouginis-Mark, P. J. 1995, Rev. Geophys. Supp., 257

Simkin, T., \& Siebert, L. 1994, Volcanoes of the World, (Tucson: Geosci. Press)

Smith, Z. A., 2000, The Environmental Policy Paradox, (NJ: Prentice Hall)

Stothers, R. B. 1983, Science, 224, 1191

Stothers, R. B. 1984, Nature, 307, 44

Stothers, R. B. 1999, Clim. Change, 42, 713

Stothers, R. B. 2000, Clim. Change, 45, 361

Toon, O. B., Turco, R. P., \& Covey, C. 1997, Rev. Geophys., 35, 41

Voight, B. 1988, Nature, 332, 125

Voight, B., \& Cornelius, R. R. 1991, Nature, 350, 695

Wood, C. A., \& Kienle, J. eds. 1990, in Volcanoes of North America, (Cambridge: Cambridge Univ. Press)

Zielinski, G. A., et al. 1996, Geophys. Res. Lett., 23, 837 